
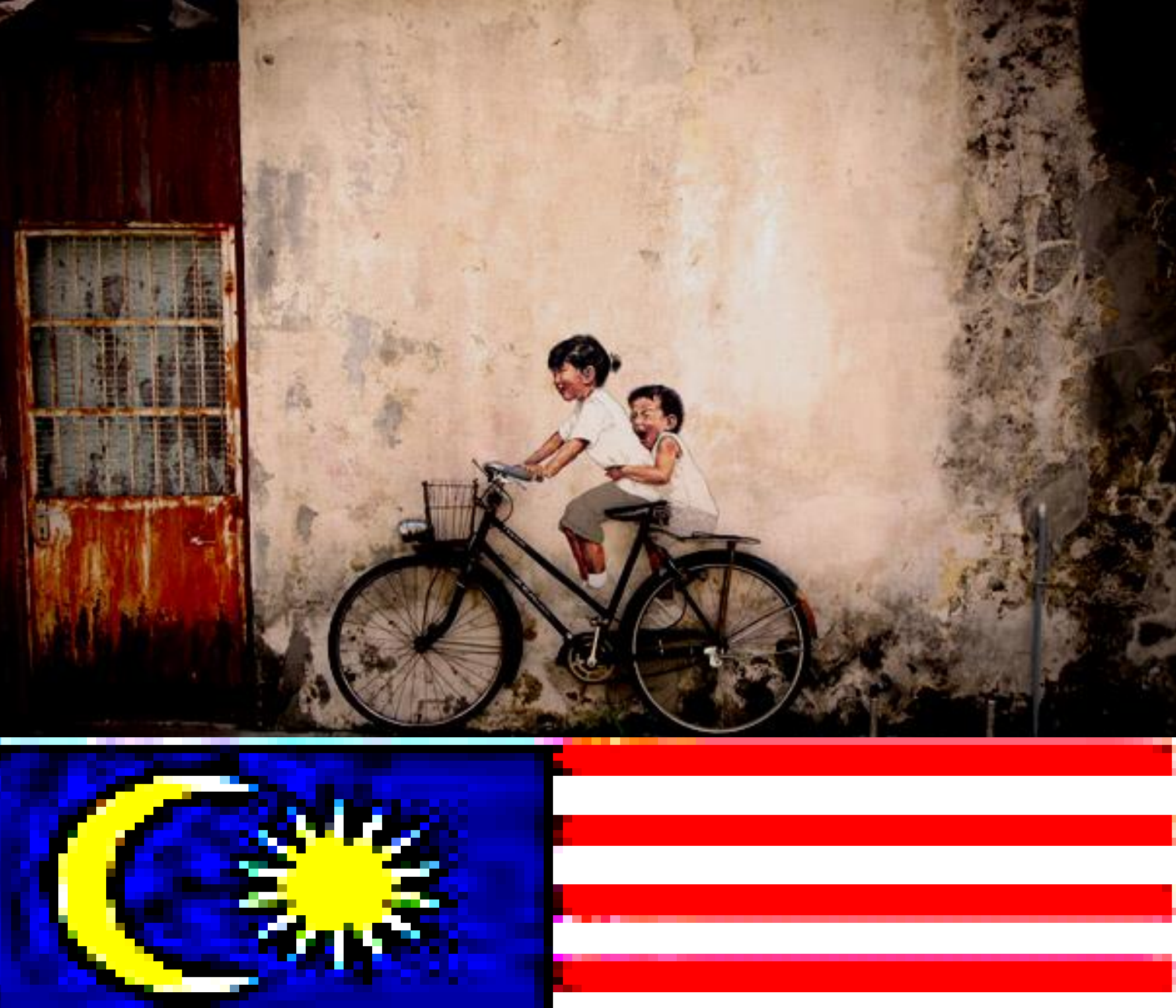

Notions of Identities in the Eyes of Malaysian Children Maya Khemlani David Wendy Yee Mei Tien 
Notions of Identities<smiles>[124IH]</smiles>

Malaysian Children

Maya Khemlani David Wendy Yee Mei Tien

This is a slightly revised version of Chapter 10 in M. K. David, J. McLellan. Y.M. Ngeow, M.L. Lean \& M.T. Yee (eds.) 2010. Ethnic Relations and Nation Building. Petaling Jaya: SIRD 


\section{Notions of Identities in the Eyes of Malaysian Children}

\section{Introduction}

After 50 years of independence recently there has been much discussion on national unity and integration in multilingual and multiracial Malaysia. Unfortunately, although we have just celebrated our 53rd year of independence, the young especially are still separated by race and religion. The existence of Chinese and Indian medium schools alongside national schools at the primary level creates a situation in which students attending these separate type of schools would have little chances of interacting with each other. For example, Chinese students who largely attend Chinese medium schools (SJKC) would not have much chance to mingle with Malay and Indian students until they reached secondary school.

With a view to the education system helping to instill national values and a sense of oneness, a compulsory course called "Ethnic Relations" was introduced in all public universities in 2007. Moreover, the government has also developed a number of programs to encourage the different races in Malaysia to socialize and mix with each other. The government allocated RM25.8 million for the implementation of the Students' Integration Plan for Unity (RIMUP) with the aim to create an environment where primary and secondary students can mix freely and learn about each other's cultures and customs.

All these efforts suggest the importance of racial harmony and understanding in nation building; especially in a multi-ethnic and multi-cultural country like Malaysia. Malaysians be they Malays, Chinese and Indians must learn how to mix and understand each other to minimize chances of misunderstandings and conflicts.

There is a stark contrast between children nowadays and children in the 1960s as children nowadays have less opportunity to freely mix with friends from other ethnic groups. This study attempts to investigate whether Malaysian children in preschools (i.e. at the age of 6) are aware of ethnic related issues and are able to mix freely with children who come from different ethnic groups. The research focuses on children because if we wish to inculcate proper values we have to go back to our beginnings - to the home where our earliest education takes place. A peaceful and harmonious tomorrow depends on whether our children are 'tainted' with issues of 'otherness' at an early age and, if this is so, this will influence their perception of other ethnic groups in the future.

Studies have shown that children acquired social cues at an early age from their environment, the media, and especially from the behavior and works of caregivers and family members (Rivera, 2007). The younger generation must be guided correctly by their parents and teachers. Normally 
children will be influenced by their parents, grandparents, teachers or their friends. Therefore, this research investigates whether family members influence the perception of children about their own ethnic group or other ethnic groups. More specifically, this study aims to answer the following question: Do children perceive differences in their own ethnic groups and those of children from other ethnic groups?

\section{Interethnic relations in Malaysia}

It is important to examine the historical background of Malaysia in order to understand better the issues related to interethnic relationship. For example, the tragic incident on 13 May 1969, 1998 incident in Kampong Rawa in Penang and Kampong Medan, Petaling Jaya in 2001 (Jayum, 2006), all indicate that race is a dominant issue in Malaysia. The ethnic riot on 13 May 1969 was actually the turning point for ethnic relations in Malaysia, but the incident failed to teach Malaysians from all ethnic backgrounds the importance of promoting good and sustainable interethnic relations. Investigations later revealed that the Kampong Medan incident (2001) was actually an interethnic confrontation which had arisen due to a simple misunderstanding (Jayum, 2006). This shows that the understanding between different ethnic groups is important so as to avoid conflict.

Research conducted by Jayum (2006), indicates that children of post-Merdeka and post-Malaysia eras simply do not mix as well as their parents and grandparents did or do. Neither do the former understand or care enough to understand each other as compared to their parents or grandparents. It can be concluded that, ethnic relations is deteriorating instead of improving despite the many measures to improve ethnic relations promoted by each successive government since the late 1960s.

Chan Huan Chiang (2004), in his study on undergraduates in the public universities, concluded that hostel roommate preferences on the basis of race and religion among undergraduates in Universiti Sains Malaysia were statistically correlated with the type of primary schools attended. This research proved the importance of instilling the concept of national unity on children. There is a need to start strengthening the concept of national unity at the grassroots level - primary school.

\section{The role of parents and teachers in fostering better inter ethnic relations}

It is said that it takes a village to raise a child. This can be interpreted that the village comprises three main institutions - family, school and community. From birth, children must be taught how to respect and honor each other's culture and heritage. Learning to interact with others is part of this process. Playing with children of other races on the playground and in friends' homes go beyond the color lines early in life. In school children must be taught about other cultures and beliefs under the same roof as others of different ethnic groups - once again cutting through the color lines. The family actually plays an important role in fostering correct value systems. 
Therefore, parents must show the values of unity during their life. They also should encourage their children to mix with others of different races so that they can better understand one another's religion, culture and way of life. Parents should encourage their children to show goodwill to all others.

Children are great observers and by the time they begin to walk they have absorbed their parents' behaviors. A child is like a sponge. Children are constantly learning and imitating what their parents do and say. Therefore, parents should avoid passing on their prejudices to their children.

According to Goleman (2007), a researcher and the author of the highly renowned Emotional Quotient (EQ) book from Harvard University, the best place for children to learn EQ is at home. The direction and values of life are formed at home. The way they speak and act are very much influenced by their parents. Even though genes play a part, it is the parental teaching that determines their future. It is known that parents bear a great responsibility in the upbringing of their children. Experiences gained from educationalists again and again prove that parents are the ones who would decide how successful their children are in adulthood. How a parent behaves in his/her daily life subconsciously plays a vital role in molding the behavior of the children.

\section{Social environment and interethnic relations}

It has been established by researchers that children at a tender age also form notions of their identities through their surroundings and eventually move out of the egocentric stage to become more socially aware of their surroundings. Gromly (1998, p. 208) explains that in the egocentric stage, children acquire an identity by "observing and imitating the actions of other people, namely their parents and older siblings" by "using the adult characteristics to describe themselves" and they are rewarded if they imitate "culturally approved behaviors" and punished if they do not. This helps children to develop an identity - one that distinguishes themselves from others. However, as they become older, they develop further identities and through these identities they are able to form and join groups-an entity where individuals share similar traits. In this process, Gromly notes that:

"Children begin to spend more time with other children and in the process discover that they can influence others. Children develop an ever-growing battery of social skills that influence their contact with other people." (Gromly, 1998, p. 243)

When children reach middle childhood (about 7 years of age), they generally have already moved on to another level in cognition, 'formal operations' (Piaget, 1995) where they are able to process more complex thoughts and information by classifying them accordingly. Inevitably, it is also an age where they become more aware of their social surroundings. In short, children acquire cultural norms through the environment and the practices within their families and later 
on, their peers and social networks. Such an expansion of socialization agents can be illustrated in Figure 1.

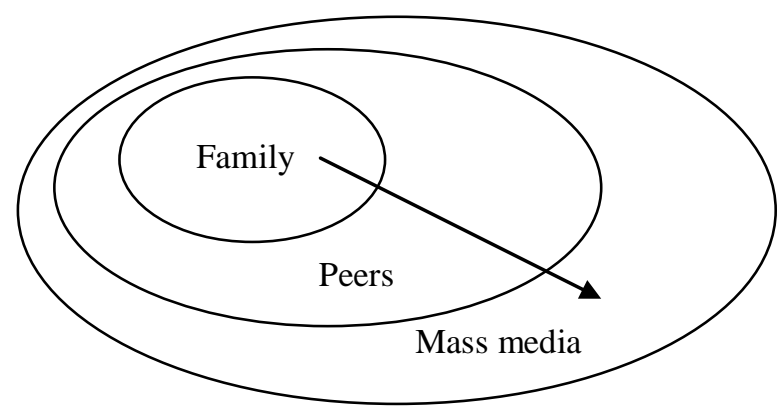

\section{Research methor}

Figure 1: Expansion of Socialization

This research gathered the data through questionnaire, observation, and interview outcomes based on audio recordings. Kindergarten children were chosen as participants in this study because the researchers would like to investigate whether children perceive differences in their own ethnic group and also in children from other ethnic groups. The participants are all attending a multi-racial pre-school in Petaling Jaya, Selangor, Malaysia.

\section{Observation}

The pre-school children from different ethnic groups: Malay, Indian and Chinese, were interviewed and observed. The observation was conducted to investigate whether children perceive differences in their own ethnic groups and children of other ethnic groups and how such differences are manifested in discourse and other practices of children.

\section{Audio-recording}

Audio-recording was the primary method of data collection. A recorder was placed on the table between the researchers and the children. The data collection began in May 2007 and lasted until the end of June 2007.

\section{Questionnaire}

Firstly, a questionnaire was developed based on the theories and concepts related to ethnic relations. According to some developmental psychologists, socialization acquired from childhood years can influence and form adults' behaviors and outlook on life (Gromly, 1998).

After completing the survey questions, pilot tests were conducted to ascertain whether the questions could be answered by the children. The questions were further edited after the pilot test. A number of problems occurred during the pilot study administration. For example, in the first interview the researchers realized that there were too many questions and that the children did not have the patience to sit for so long to listen to the questions. They were running around 
and playing with their friends after answering some questions. Besides, when questions were asked about "best friends" and "casual friends", the children actually did not understand the concept. For children, friends are "friends"; they could not differentiate the types of friends. This appears to confuse the children and they also felt bored because they appeared to be answering the same question. As a result of this input from the children the questions were revised and another pilot test was conducted. Pictures were used as stimuli to aid the children to understand the questions.

\section{Interview}

Besides the questionnaire, the researchers also conducted interviews with the children in the kindergarten. After each interview, the researchers had to listen to what had been recorded during the interview and transcribe the interview. This was a lengthy process. The researchers had to listen to the same interview several times to obtain the data. In addition, the text had to be translated as there were some children who spoke only Mandarin or Malay.

\section{Results}

Graph 1 showed that $64.6 \%$ of the children perceive differences between their own ethnic and other ethnic groups. Out of this total $(64.6 \%), 50.8 \%$ of the children said they knew how to differentiate the different ethnic groups based on the color of the skin while $13.9 \%$ said they differentiated the differences according to the language used. The result in Graph 1 showed that $55 \%$ of the Malay children, $70 \%$ of the Chinese children and $60 \%$ of the Indian children knew how to differentiate between their own ethnic group and other ethnic groups.

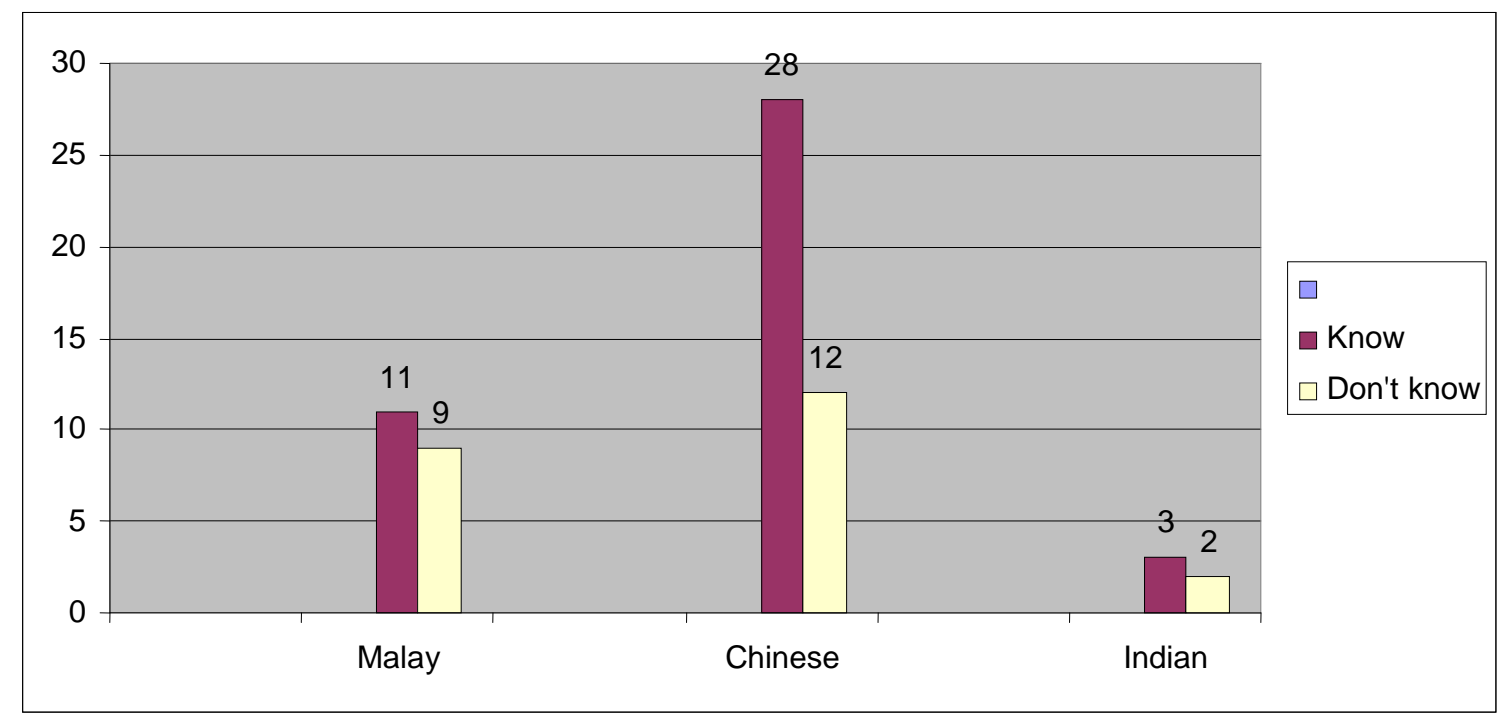

Figure 2: Graph 1: Children's Awareness of their Own Ethnic Group and Other Ethnic Groups 
When the researcher asked the children which ethnic group she (the researchers) belonged to, the children answered correctly. However, when one of the researchers asked a child if he recognized the Indian teacher who had a dark complexion, the child was quiet for a long time and did not answer the question. He looked scared and kept looking at the teacher. The researcher then comforted the child and said "Never mind, it's alright, just tell me", and then the child replied softly that she was an Indian. He might have been afraid of the teacher. This probably indicated that the child was quite sensitive to the other ethnic groups. This was supported with his later comment, when the researcher asked if he knew how to differentiate Malays, Indians, and Chinese, he answered "the color of skin." This is shown in the transcript in Examples 1-3.

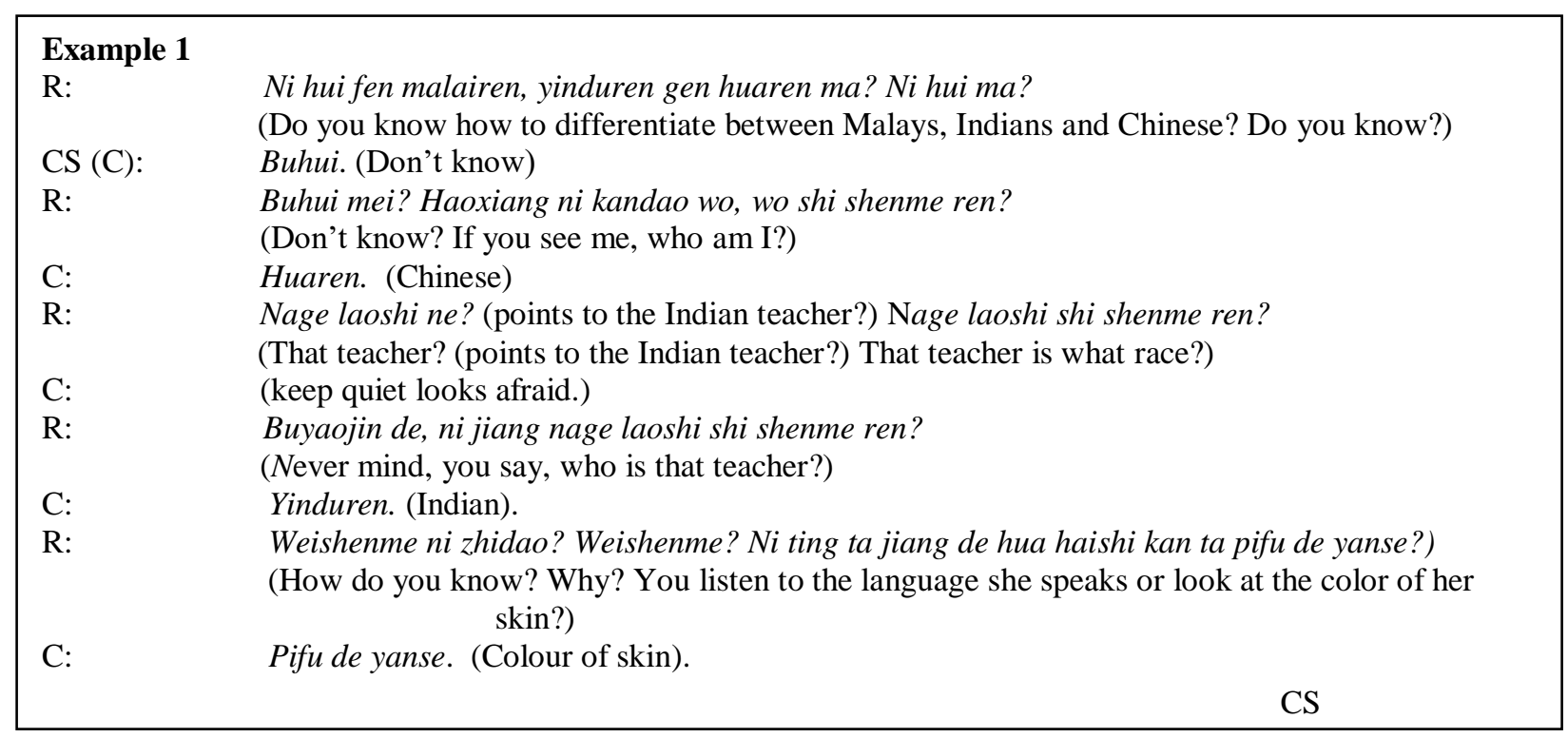

The child in example 2 pointed at his own hand and said "This color is Chinese". Then he described Malays as those having brown skin and Indians having black skin. He seemed confident about what he was saying and commented that it was his mother who had taught him to differentiate based on skin color. 


\section{Example 2}

$\mathrm{R}$ :

Ni hui fen ma? Ni xiangyixia, ni hui fen ma? Bu hui fen? Ni buhui fen tamen shi malairen, yinduren haishi huaren? Dong ma? Ta gen ni jiang ni cai dong a?

(Do you know how to differentiate? You try to think, do you know how to differentiate or not? Don't know? You don't know they are Malay, Indian or Chinese? Do you know? He tells you then only will you know?)

CWH(C): $\quad$ Wo zhidao. (I know.)

$\mathrm{R}$ :

Ni zhidao, a ni zenyang zhidao? (You know, how do you know?)

C:

(points to his hand) Yinwei wo de wo de mami gen wo jiang zheyangzi de color jiushi huaren, brown color jiushi malairen, black color jiushi yinduren.

(Know, because my mother tells me color like this (point his hand) is Chinese, brown color is Malay, black is Indian.)

\section{CWH}

\section{Example 3}

$\mathrm{R}:$

Ni hui fen malairen, yinduren gen huaren ma? Ni hui ma?

(Do you know how to differentiate Malay, Indian and Chinese or not? You know?)

F:

Buhui, wo hui malairen ba liao. (Don't know, I only know Malays.)

R:

Ni hui malairen, ok, ni zenyang fen? Haoxiang ni kandao wo ni dong wo shi shenme ren ma?

(Nods). Wo shi shenme ren?

(You know Malay, ok, how do you differentiate? Like you look at me, you know what I am?

I am what people?)

F: $\quad$ Tang ren. (Chinese.)

R: $\quad$ A, then nage laoshi ne? (points to the Indian teacher.)

(Then the teacher?) (points to the Indian teacher.)

F: $\quad$ Yinduren. (Indian)

R: $\quad$ A, ni zenyang zhidao? Ni zenyang zhidao? (How do you know? How do you know?)

F: $\quad H u i$ yinwei tamen de yanse. (Know, because of their color)

R: $\quad$ Shenme yanse shi shenme ren? (What color - what people?)

F: $\quad H e i s e$ shi yinduren, hese shi malairen. (Indians are black, Malays brown.)

R: $\quad H u a r e n ~ l e i ?$ (Chinese?)

F: $\quad$ Huaren shi baise. (Chinese are white) 
Initially $\mathrm{F}$ had said that he was not able to differentiate different ethnic groups. However, when the researcher asked her which ethnic group the Indian teacher belonged to and which group the researcher belonged to, she managed to differentiate based on the color of the skin.

Example 4 demonstrates how the Malay children differentiate between ethnic groups.

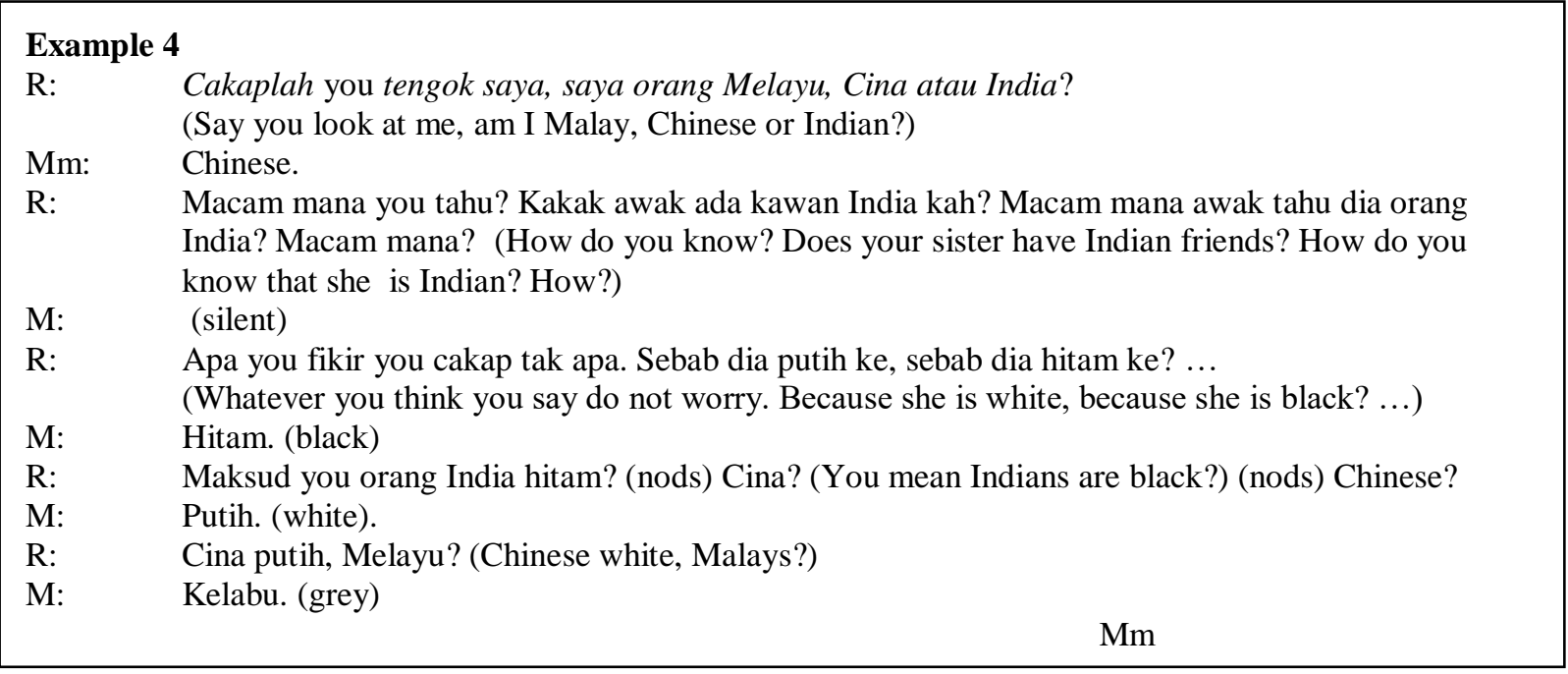

Mm in Example 4 indicated that he knew how to differentiate between the ethnic groups based on color. He said Chinese are white, Malays are grey and Indians are black. He explained that he knew Indians are black because his sister had Indian friends.

The above examples showed that children knew how to differentiate the different ethnic groups based on the color of the skin.

Showing pictures to the children was another method used to determine how the children perceive differences in their own ethnic groups and those from other ethnic groups. One of the questions asked was "Look at the picture, who would you like to be your friend?" Table 1 indicates how the children from different ethnic groups chose their friends.

Table 1: Friends choice from the picture stimulus given

\begin{tabular}{|c|c|c|c|c|c|c|c|}
\hline Ethnic & $\begin{array}{c}\text { Malay boy } \\
\text { (MB) }\end{array}$ & $\begin{array}{c}\text { Malay } \\
\text { girl } \\
(\mathbf{M G})\end{array}$ & $\begin{array}{c}\text { Chinese } \\
\text { boy } \\
(\mathbf{C B})\end{array}$ & $\begin{array}{c}\text { Chinese } \\
\text { girl } \\
(\mathbf{C G})\end{array}$ & $\begin{array}{c}\text { Indian } \\
\text { boy } \\
(\mathbf{I B})\end{array}$ & $\begin{array}{c}\text { Indian } \\
\text { girl } \\
(\mathbf{I G})\end{array}$ & $\begin{array}{c}\text { MB, MG, IB, } \\
\text { IG }\end{array}$ \\
\hline Malay & 6 & 0 & 7 & 6 & 0 & 1 & 0 \\
\hline Chinese & 3 & 0 & 19 & 13 & 0 & 5 & 0 \\
\hline Indian & 0 & 0 & 2 & 0 & 1 & 1 & 1 \\
\hline Total & 9 & 0 & 28 & 19 & 1 & 7 & 1 \\
\hline
\end{tabular}


Table 1 show that $65 \%$ of the Malay children chose Chinese to be their friends, while $30 \%$ chose friends from their own ethnic group. $80 \%$ of the Chinese children chose friends from their own ethnic group, and only $7.5 \%$ chose Malays to be their friends and $12.5 \%$ chose Indians as their friends. 2 out of the 5 (40\%) Indian children chose friends from their own ethnic group and also $40 \%$ chose Chinese to be their friends.

Comparing the different ethnic groups, Table 1 indicated that $80 \%$ of the Chinese children chose friends from their own ethnic group and this is the highest percentage as compared to the choice of the Malay and Indian children. This suggests that Chinese children were able to perceive differences between their own ethnic group and other ethnic groups. Table 2 shows the reasons given by the children as to why they chose people from the respective ethnic groups as their friends.

Table 2: Reasons for their choice of friends

\begin{tabular}{|l|l|l|}
\hline Reason & No. & \% \\
\hline Because she / he is beautiful / handsome, nice, cute, good & 26 & 40 \\
\hline Because he / she is a boy / girl & 2 & 3.08 \\
\hline According to the ethnic groups & 19 & 29.23 \\
\hline Have fun talking with me & 4 & 6.15 \\
\hline Because the clothes are beautiful & 3 & 4.62 \\
\hline Because I like to have a brother & 1 & 1.54 \\
\hline Because I want to be like him & 1 & 1.54 \\
\hline Don't know & 9 & 13.85 \\
\hline Total & $\mathbf{6 5}$ & $\mathbf{1 0 0}$ \\
\hline
\end{tabular}

Table 2 shows that $40 \%$ of the children said they chose the people from that picture shown to be their friends because that person looked beautiful/handsome/nice/cute/good. In choosing their friends from a picture stimulus it appears they ignored ethnicity and only $29.23 \%$ of the total children said they choose a friend from the same ethnic group.

\footnotetext{
Example 5

R: $\quad$ Why did you choose him to be your friend?

Y: $\quad$ Yinwei ta shi huaren. (Because he is Chinese).
}

In Example 5, YH chose his friends based on ethnicity. $\mathrm{CWH}$ in Example 6 said he chose a Chinese to be his friend because he did not like black, which means if Malays and Indians are 
black, he would not like them. This showed that this child differentiated ethnicity based on color. He knew that Chinese are fairer than Malays and Indians. He chose his friend based on color.

\begin{tabular}{|ll|}
\hline Example 6 & Yinwei ta shi huaren. (Because he is Chinese). \\
$\mathrm{C}:$ & Yinwei ta shi huaren? Weishenme? Ni xihuan he huaren zaiyiqi ba le? ni bu \\
$\mathrm{R}:$ & xihuan malairen he yinduren a? weishenme, yinwei tamen heihei a? (he nods). \\
& (Because he is Chinese? Why? You like to be with Chinese only? You don't like \\
& Malays and Indians? (he nods ). \\
$\mathrm{C}:$ & Wwo bu xihuan hei. (I don't like black.) \\
$\mathrm{R}:$ & Nhi bu xihuan hei, weishenme? (You don't like black, why?) \\
$\mathrm{C}:$ & Wo bu xihuan black color. \\
& \\
\end{tabular}

Besides the Chinese children, the Malay and Indian children also chose their friends from their own ethnic group. This is seen in Examples 7-9.

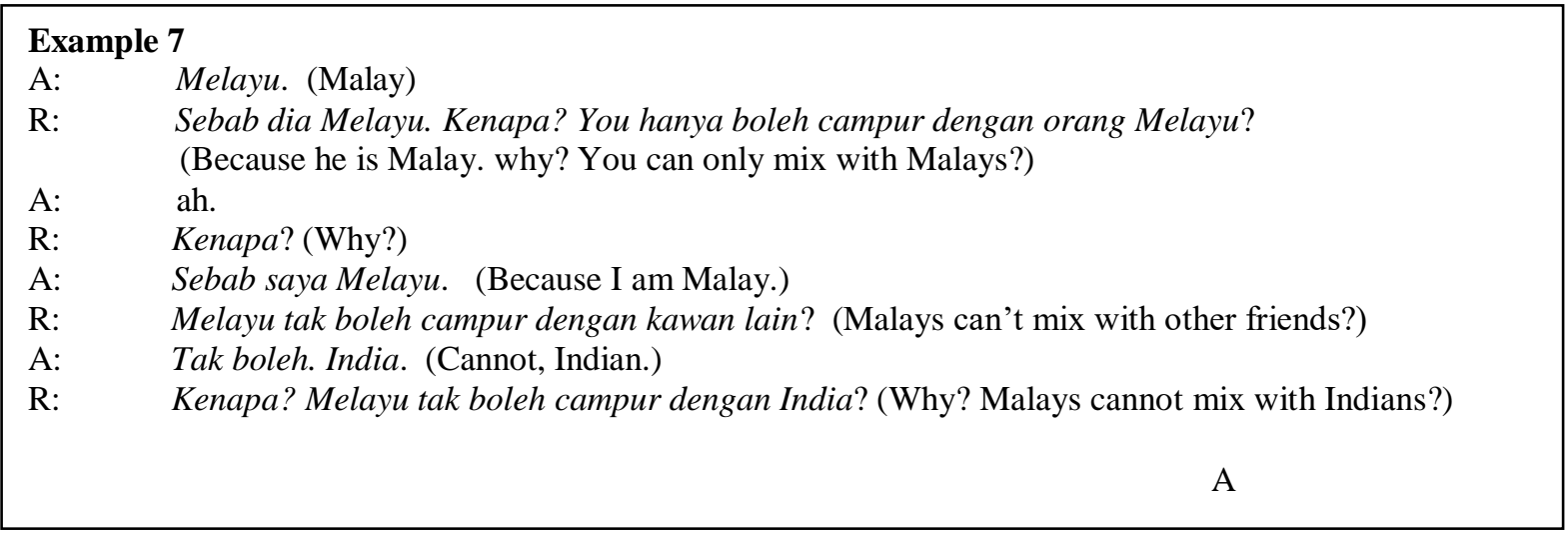

These children were quite sensitive to the issue of ethnicity. ' $A$ ' said that he chose Malays to be his friend because he is Malay. He said that Malays cannot have friends of other ethnic groups like the Indians. Besides A, another respondent also said that he chose friends according to his own ethnic group. This is illustrated in Example 8.

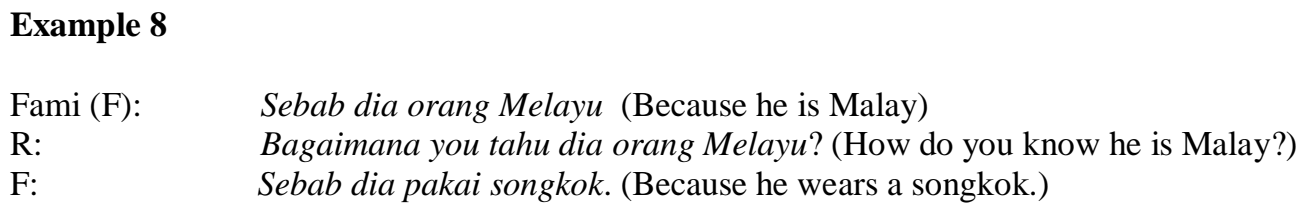

$\mathrm{F}$ in Example 8 said he chose friends based on ethnicity. He was aware that a boy in the class was Malay because Malays wore songkoks. Similarly S an Indian (Example 9) chose a friend because he also was an Indian, just like him. 

Example 9
R: $\quad$ Why did you choose her to be your friend?
$\mathrm{S}$ : $\quad$ Because she is Indian.

A survey was conducted to determine if the children have best friends from different ethnic groups. The results are shown in Table 3.

Table 3: Do they have best friends from different ethnic groups?

\begin{tabular}{|l|l|l|l|l|l|l|}
\hline \multirow{2}{*}{ Ethnic } & Malay & Chinese & Indian & \\
\cline { 2 - 7 } & Yes & No & Yes & No & Yes & No \\
\hline Malay & 20 & 0 & 0 & 20 & 3 & 17 \\
\hline Chinese & 8 & 32 & 40 & 0 & 5 & 35 \\
\hline Indian & 2 & 3 & 4 & 1 & 4 & 1 \\
\hline \multirow{3}{*}{ Total } & $\begin{array}{l}30 \\
(46.15 \%)\end{array}$ & $35(54.85 \%)$ & $\begin{array}{l}44 \\
(67.69 \%)\end{array}$ & $21(32.31 \%)$ & $\begin{array}{l}12 \\
(18.46 \%)\end{array}$ & $53(81.53 \%)$ \\
\hline
\end{tabular}

Table 3 shows that only $46.15 \%$ of the children have Malay best friends, $67.69 \%$ of the children have Chinese best friends and $18.46 \%$ of the children have Indian best friends. From Table 3, it can be seen that most of the Malay and Chinese children did not have best friends from other ethnic groups.

Table 3 shows that $80 \%$ of the Chinese children did not have Malay best friends and $87.5 \%$ of the Chinese did not have Indian best friends. Similarly, most of the Malay children said they did not have friends from other ethnic groups. For example, all the Malay children said they did not have best friends who were Chinese and $85 \%$ of the Malay children said they did not have best friends who were Indian. However, the Indian children had best friends not only from their own ethnic group but also from other ethnic groups.

Example 10 is an excerpt from the respondents who indicated that their mother or their parents had taught them how to differentiate between the different ethnic groups.

FPY in Example 10 indicated that she knew how to differentiate between the different ethnic groups. When the researcher asked her who taught her how to differentiate, she said it was her mother. The extract shows that her mother taught her how to differentiate Malay, Chinese and Indian based on the color of their skin. 


\begin{tabular}{|ll|}
\hline Example 10 & \\
$\mathrm{R}:$ & A, ni zenyang zhidao? Ni zenyang zhidao? (How do you know? How do you know?) \\
$\mathrm{F}:$ & Hui, yinwei tamen de yanse. (Know, because of their color) \\
$\mathrm{R}:$ & Shenme yanse shi shenme ren? (What color?) \\
$\mathrm{F}:$ & Heise shi yinduren, hese shi malairen. (Indians are black, Malays brown.) \\
$\mathrm{R}:$ & Huaren lei? (Chinese?) \\
$\mathrm{F}:$ & OK, shui jiao ni de? Shui jiao ni zheyang fen? \\
$\mathrm{R}:$ & (OK, who taught you this? Who taught you to differentiate like this?) \\
$\mathrm{F}:$ & \\
& \\
\hline
\end{tabular}

T, a Malay child in Example 11, can also differentiate the different ethnic groups based on the color of their skin, and he too claimed this was taught by his parents.

\section{Example 11}

R: $\quad$ You tahu bezakan orang Melayu, Cina dengan India tak?

(Do you know how to differentiate between Malays, Chinese and Indians or not?)

T: $\quad$ Tahu. (know) Orang India muka dia hitam sikit. (The face of an Indian is a little black.)

R: $\quad$ Yang lain? (the others?)

T: $\quad$ Cina pula warna muka dia putih. (the faces of Chinese are white)

R: $\quad$ Cina putih, Melayu? (Chinese white, Malays?)

$\mathrm{T}: \quad$ (keeps quiet).

R: $\quad$ You tahu itu sahaja? (you only know this?)

T: $\quad$ (Nods).

R: $\quad$ Siapa ajar you? (Who taught you?)

$\mathrm{T}$ : Mak dengan ayah yang ajar. (Mother and father taught me.)

' $A$ ' in Example 12 also said that her mother had taught her how to differentiate between the different ethnic groups. Her mother taught her that Chinese are fairer.
Example 12
R: $\quad$ Macam mana you tahu saya Cina? Macam mana you tahu orang itu India, Cina atau Melayu? Macam mana you tahu saya Cina?
(How do you know I am Chinese? How do you know that people are Indians, Chinese or Malays? How do you know that I am Chinese?)
A: $\quad$ My mummy teach.
R: $\quad$ Your mummy teach? How your mummy teach? How your mummy teach I am Chinese? 


\section{Discussion}

Based on the findings of this study, it is clear that children, even at such a tender age have developed perceptions about their own ethnic group as well as perceptions about the different ethnic groups. Most of the children were able to differentiate friends from the different ethnic groups based on the color of their skin. The majority of these children also claimed that it was their parents who had taught them how to differentiate based on color. It was unclear why parents' preferred to use the 'color of the skin' as the demarcation between different ethnic groups but such demarcation definitely entails the distinction of group identities; and these identities are usually opposing i.e. 'we' vs. 'them' (David \& Zuraidah, 2005). Such identities are usually classified as 'in group' and 'out group'. According to Tajfel (1982), members of an 'in group' usually have positive views of themselves but hold negative views of the 'out group'. This implies that if children starts identifying people with the same skin color as 'in group' and people with different skin color as the 'out group', this might eventually lead to prejudgment and stereotyping. If such a prejudgment and stereotype is not rectified, it will develop into a value system / beliefs system within the 'in group' about the 'out group'.

It is very important for parents to realize that they are their children's 'first teacher'. Children acquire an identity by observing and imitating the actions of other people, namely their parents and older siblings (Gromly, 1998). Instead of differentiating the ethnic groups by the color of their skin and associating them with negative beliefs, children should be taught how to respect differences. Children should be encouraged to mix around, playing with friends beyond the color lines to learn the beauty of each difference and understand the other's culture and way of life. In a world where cultures increasingly converge and intermingle with each other, teaching children the values and skills of 'learning to live together' become a priority.

Children as always are 'color blind' and mix freely without any barriers with anyone and everyone. As indicated in this study, when the children were asked to choose their friends based on the picture shown, most $(40 \%)$ of the children revealed that the main reasons for their choice of friends were based on the looks i.e. the boy/girl in the picture looked beautiful, handsome, nice, cute and good. There was no element of ethnicity. This implies that though the children were able to perceive ethnic differences, these were not the determining factor for their choices of friends. This finding also reflects the cognitive development in children.

Children start to acquire norms through the environment and the practices within their families and later on, their peers and social networks (Piaget, 1995). Basically then the children in this study became aware of ethnic differences mainly based on the color of the skin and this knowledge was disseminated by parents. The present generation has a moral responsibility to bequeath to future generations a culture of peace instead of ethnocentrism. 


\section{Conclusion}

This study revealed that the children's perception for their own identity as well as that of other ethnic groups is essentially based on skin color. This perception of identity based on skin color is the result of the influence and teaching of their parents at home. As such, the children appeared to have developed certain racial stereotypes at their young age as their parents have inculcated into their minds how to categorize and compare ethnic groups. These stereotypes and prejudices about other ethnic groups are learned behaviors acquired from their respective families are unfortunate as it will affect their perception and interaction in the future. It is thus recommended that parents should raise their children to be color blind and to inculcate in their minds from young, an appreciation for our racial and cultural diversity.

\section{References}

1. Chan, H. C. (2004). Racial polarization and room-mate choices among university students. In Cheah Boon Kheng (Ed). The challenge of ethnicity: Building a nation in Malaysia (pp. 9-39), Singapore: Marshall Cavendish International.

2. David, M.K. and Zuraidah Mohd Don (2007). A plea for the use of authentic data in the ESP classroom. Journal of Communication Practices. 41.

3. Goleman, D (2007). Emotional intelligence. London: Bloomsbury Publishing PLC

4. Gromly, A. (1998). Lifespan human development. Orlando, FL: Harcourt Brace.

5. Jayum Anak Jawan (2006). Inter-ethnic relations in Malaysia: Selected readings. Serdang, Malaysia: Universiti Putra Malaysia Press.

6. Piaget, J. (1995). Sociological Studies. London: Routledge.

7. Rivera, C. (2007). Nipping bias in the bud - Some preschools are using a special program to teach their students, before prejudices take hold, to respect cultural, racial and religious diversity. Retrieved Feb 10, 2009 from http://articles.latimes.com/2007/jul/16/local/mebias16.

8. Tajfel, H. (1982). Social psychology of intergroup relations. Annual Review of Psychology, 33, 1-39. 


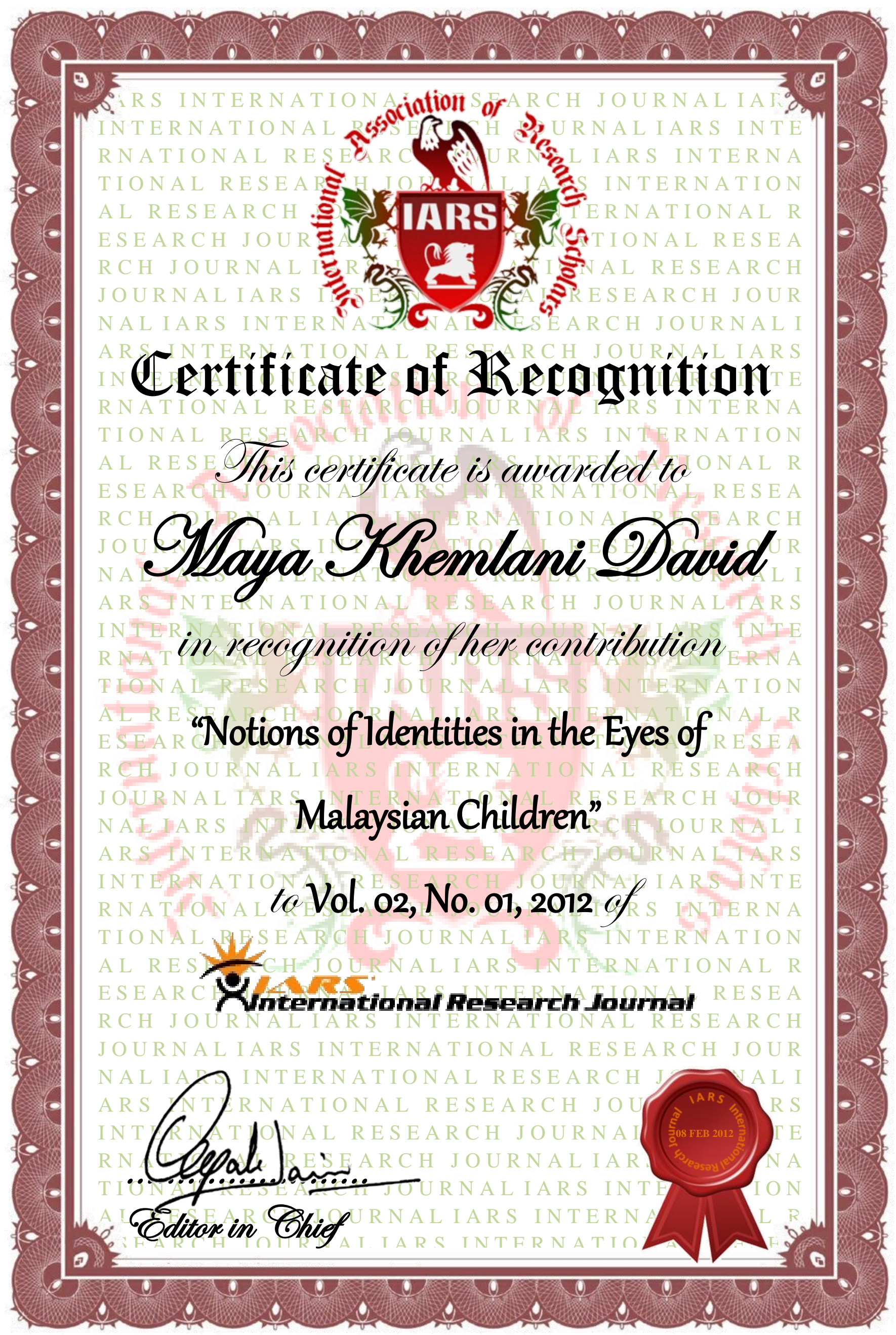

